\title{
Model Service Life Skills Counselling (Life Skills Mentoring) Based Tri Hita Karana Citizens Group to Learn in the District Badung, Gianyar and Singaraja Bali Province
}

\author{
A.A.NGURAHADHIPUTRA \\ Program Study Tuition and of Konseling, Faculty Science Education \\ Institute of Teachership and Science Education ( IKIP) PGRI Bali.
}

\begin{abstract}
The study has been intended to develop life skills counselling models based on the tri hita karana concept is needed because counselling services in most society tend to be academic and vocationally oriented. Therefore, models of life skills counselling are obligatory. Four steps were taken in the study. First, preliminary overviews of general life skills education program in the society. Second, developing 'hypothetical' life skills counselling models based on the tri hita karana and formulating an early life skills counselling services. Third, conducting a model validation though seminars, and trying -out models and data analyses. At this stage, the researcher conducted data analyses between pre-test and post-test implementations. Fourth, based on the data analyses, the researcher formulated a final model of the Tri hita karana-based counselling service and further socialized, disseminated, and strengthened the places of counselling activities the in society. In general, this research has achieved the targeted goals; to develop a tri hita karana-based models in life skills counseling work. The model can be applied by tutors, technical resource persons, counselors, organizers of fasilitators at the Province of Bali.
\end{abstract}

Key word: Tri hita karana, self-recognition, self-learning, independence, communicative, cooperative \& colaborative, and solidarity

Developmensts of life skills counseling service model outside the school have been perceived as an urgent need, especially in providing life skills counseling (guidance and life skills) of residents in the community study groups (especially in Badung, Gianyar and Singaraja regencies). In the future, labor counseling and practical guidance and counseling will not only be limited to the order of the school, but on the broader society, where the school is only one part of the social order. Faced with such developments, PS-BK must be anticipatory and proactive in order to fix the performance of its graduates, to prepare the program that not only meets the needs and expectations of today's environment, but the needs and expectations of the environment in the future, even-handed field field of new services to the public. In other words, PS-BK not only meet the needs of the community, but to create public needs guidance and counseling services (Natawidjaja, 2000: 77).

Observing the conditions of implementations of guidance on community living skills, signaling that have not found the model Life Skills Counseling services (guidance and life skills) based on the tri hita karana concept is effective to improve the general skills life skills (general lifeskills) on citizen groups to learn life skills. Efforts by the government and associations of guidance and counseling (ABKIN) as well as mentors in the school experience so far, apparently not enough to provide further stimulus to discover and develop a model of Life Skills Counseling services (guidance and life skills) based tri hita karana is effective against the citizens group learning in the community. 
To stimulate activity of resident tutors study groups, this research is to focus on efforts to find and develop a model of life skills counseling services (guidance and life skills) based tri hita karana in learning life skills. Model guidance service aimed at the citizens of this target group to learn life skills in three districts, namely Badung, Gianyar, and Singaraja within the Bali Province which will operationally involve the civil learning / tutor, technical resource persons, and companions/mentors. The patterns of guidance services performed start from designing intervention model life skills counseling (guidance and life skills) for those study groups that are based on the identification of various aspects of the necessary life skills, potential, and constraints faced by the citizens group to study, test model Life Skills Counseling intervention (counseling life skills) based tri hita karana, up to evaluation, and dissemination, dissemination and strengthening the position of life skills counseling services (guidance and life skills) based on the tri hita karana concept in the community settings.

The results of the preliminary studies conducted by researchers at the coverage of unity in 2008 and coverage of the second year of 2009 were intended to know the initial conditions on the mastery of life skills learning programs compiled indicates that for one school year covering $30 \%$ theory and practice of $70 \%$. The curriculum is based on learning needs and goals of community living skills dipokuskan guidance on specific skills (Specipic lifeskills), viz. Academic and vocational skills. At the end of the learning process conducted evaluation of the level of citizen groups to learn both theory and practice. After the learning process, the independence of funds given to the study group as a managed venture capital group. In addition, preliminary studies also provide a focus model of learning life skills education programs are developed on the acquisition of academic and vocational skills alone. The findings on the scope of this second year as well as one proof that learning life skills education program less attention to aspects of general skills (general lifeskills) but emphasize specific aspects of skills (specific life skills), the skills that are academic and vocational.

Implementations of the life skills counseling service models (guidance and life skills) based on the tri hita karana concept in education, which is aimed at changing the behavior pattern of the citizens' groups to learn life skills. These aspects are developed in this approach also includes aspects of cognitive, interpersonal relationships, self-concept, affective and health conditions in learning. These aspects are developed in an integrated manner has been implicit in the concept of tri hita karana, which maintain the balance between man and gods (parahyangan), maintaining the balance between man and man (pawongan), and maintain a balance between humans and the natural environment (palemahan). The steps are as follows: (1) Concept of parahyangan: implying picture of the world's people live aims to achieve physical and spiritual welfare (moksartham jagathitaya caiti dharma), foster the attitude of mutual understanding between each other and respect differences (rwa bhineda), in This citizens group learning capable of understanding the strengths and weaknesses, a willingness to take risks, and develop mutual understanding. The purpose of this counseling approach is to develop skills to deal with problems specific to study and work is being experienced at present and which may arise in the future. In other words, the objective approach of this guidance is to help people learn to develop themselves into groups of skilled personal (skilled-person), (2) pawongan concept: to teach people to always think (wanacika), said (wacika), and acting or doing (kayika) good (tri-rich parisudha), teach a man to always refrain from violence and cruelty (tat twan asi), in this case citizens study group was able to convey ideas or messages, the behavior of flexible, and able to express her feelings, capable of working on a joint task, and awakening a sense of togetherness. The purpose of this counseling approach is that all residents learn life skills groups have strengthened the urge toward survival, maintenance and development. They can have a good experience or not good in the process of obtaining and studying ways to maintain and develop life skills, and (3) the concept palemahan: implied value of life learn to understand human attitudes tolerance, harmonious bad destiny (paras-paros salunglung sabayantaka saharpanaya), implies man will not do damage, and natural memporandakan (anuduhkna ajnyana sandhi), in this case citizens study group showed an attitude of mutual understanding, able to cooperate, work in groups, solve problems peacefully and appreciate cultural diversity. The purpose of this counseling approach is that every human being 
(citizen study groups) have the courage to confront or surrender to the weakness of life skills, develop life skills strengths, maintain and develop life skills.

In accordance with the purpose of research, the design of the research is design research and development (Borg, 1979; Borg and Gall, 2003) by first doing modifi-cation. While the approach used was qualitative and quantitative approaches in an integrated way (mixing) in order to achieve optimal results (Creswell, 1994: 145). Denzin (1970) revealed that a combination of strategies in the study aims to examine the same research problem that will increase attention to the validation of conclusions are enriched with data (in Branen, 1993: 13). In the process of data collection, qualitative approach emphasizes the role of researchers as the main instrument (key instrument) through observation and depth interviews. While quantitative approaches with experimental tests performed using the one-group pretest-posttest design (Fraenkel and Wallen J Norman E, 1993: 246) is to analyze the data between before the application of the model (pre test) and after application of the model (post test) on citizen groups to learn life skills.

A combination strategy of the above approaches are used to enrich the data to obtain a validation of conclusions on issues of concern in the research and development services model life skills counseling (life skills guidance) based on the Tri Hita Karana citizen study groups in society so that it can provide a practical working description life skills training event Counseling services (guidance and life skills) based Tri Hita Karana in society. The objective of this research is to learn the skills group residents living in three regions in the province of Bali LCS District. Some of the indicators used in establishing the location of the study are: 1) citizen study groups that have no life skills, 2) most of the citizens group to study drop-outs or drop-outs, and 3) all people in study groups that have no future plans and weak in attitude and in skills. Next, set three areas where research is: Badung, Gianyar and Singaraja Bali Province that have been implemented through a life skills coaching guidance Sanggar Learning Activities (LCS), which involves civil learning / tutor, technical resource persons, facilitators / mentors, and organizers in District level and the manager at the village level.

\section{LITERATURE REVIEW}

International Education Conference (International Conference on Education-ICE) and the Regional Consultation Member States in Asia-Pacific, held in Geneva in 1994, is the regional meetings and workshops hosted by Unesco. Where in this meeting to discuss the vision APNIEVE (Asia-Pacific Network for International Education and Values Education), namely, Education for the XXI century,: Learning to live together in peace and harmony is a process that is dynamic, holistic and lifelong where mutual respect, caring (care) and sharing, compassion, social responsibility, solidarity, willingness to accept diversity and tolerance among individuals and between groups (ethnic, social , culture, religion, national and regional) didarahdagingkan and practiced together to solve problems and seek the direction of a fair and free, peaceful and democratic. (UNESCOAPNIEVE, 1996, translation WP Napitupulu, 2000; 8).

In that case, it is necessary to consider how education can contribute to change the democratic citizen study groups towards social responsibility, sharing, tolerance, and accept the diversity that exists in society. In the Second Long-Term Development Goals (Guidelines, 1993, Chapter III, Section C) contained the following formula:

General targets second long term development is the creation of human quality and the quality of Indonesian society that developed and independently in an atmosphere of peace and Sejahtra physically and spiritually, in order the life of the community, nation, and a state based on Pancasila, the Indonesian people's life in an atmosphere which is too berkeseimbangan and harmony in relationship between human beings, human society, human nature and the environment, human beings with God Almighty.

Based on the above explanations, the fact is that every citizen group learns life skills in three districts, namely: Badung, Gianyar and Singaraja Bali Province in which the role of government in particular related parties is less attention to the psychological aspects of thinking skills in training and action needed by the citizens group to study and only emphasize the pattern of guidance aimed at providing technical assistance, ie 
grants or venture capital, established business partners, and help marketing their business products. Therefore, implementation of Life Skills Counseling services (guidance and life skills) in the community is a very urgent problem and giving guidance about life skills relevant to the demands of the needs of study groups to acquire the skills to think and act to help people learn to develop itself into a group personal skilled (skilled-person) in accordance with its cultural environment.

\section{Lifeskills Counselling}

Life skills guidance (lifeskills counseling) is also called Helping lifeskills (LSH) or lifeskills therapy is "an integrative approach to help clients develop skills to be able to help themselves (self-Helping)."

The word "skills" with respect to (1) area (areas) skills, such as listening skills and disclosure, (2) the level of competence, such as skilled and unskilled, and (3) knowledge and sequence of choices. Skills (skills) can be defined as the ability to create and implement sequensi option to achieve the goal. For example, if clients want to have the assertiveness skills or manage stress, then he must create and implement effective choices to achieve that desire (Joseph, S., 2003: 1).

While life skills is defined as the attitude and ability to deal with various problems of life fairly, proactive and creative to find a solution. Skills or life skills include general skills (general life skills) and specific skills (specific life skills). General proficiency consists of top (1) personal skills (personal skills): selfknowledge skills, learning skills, adaptability skills, troubleshooting skills (copeability), thinking skills, independence and responsibility, and (2) social skills (social skills) : communication skills, ability to work cooperatively and collaboratively, and the attitude of solidarity. While specific consisted of 1) academic skills, and 2) vocational skills (kareer).

Counseling, life skills in carrying out its approach is based on four assumptions, which are as follows:

a. Many problems are brought to the counselor is a reflection of client learning outcomes.

b. Although the external factors contributing to the problem client, but the most influential is the weakness of the client in thinking and acting to resolve the issue (lack of skills to think and act). c. An effective counselor is capable of creating "Helping supportive relationship", and train the client to have the skills to think and act.

d. The main purpose of counseling is to help clients to be able to help themselves (self-Helping) by way of developing thinking skills (thinking skills) and skills to act (action skills) so as to overcome the problems experienced now, and able to prevent future problems.

2. Process of learning life skills education program The process of learning life skills education program implemented in the community through three stages as follows: First, the preparation phase of life skills education orientation followed by a citizens group studying, organizing provincial village-level managers. Resource persons in order to equate perceptions about life skills education program that includes materials such as: the concept of life skills education, organizing models, learning models, models of mentoring, business management, administrative activities, and the formation of life skills education groups according to type. Second, the implementation phase of the second stage is held the learning process respective groups followed by every citizen study groups that include the materials in accordance with GBPP / curriculum that had been developed. Teaching and learning activities guided by a technical resource persons from relevant institutions and learning resources from the local area, so that guidance can be practically implemented using participatory methods. At this stage the learning process as follows: (1) study the theoretical techniques and practical skills of how to organize and manage the business in accordance with its prospects and (2) after at least a basic knowledge mastered by every citizen study groups, held the practice and test / practice directly in each group and in one of the institutions engaged in the business, according to the skills ditekuni. Third, follow-up phase is the last stage by conducting an evaluation in the form of written and practical tests, the results are the basis used to determine the programs and Follow-Up Action Plan (RKTL). The end result of this learning process is expected of every citizen study groups ready to work, tried, and independent (BBM) in groups and sub groups.

\section{RESULTS AND REVIEW}

The findings of the preliminary research conducted by the researchers to determine the initial conditions on the mastery of general skills life skills citizen study group showed that an average of 43.68 percent of 
group learning general life skills to master skills from three areas of research, namely: Badung, Gianyar, and Singaraja Bali Province (pre test).

The subjects in this study were the residents learn life skills groups in the three districts of Bali Province. While aspects studied were the effectiveness of the model Life Skills Counseling (guidance and life skills) based on Citizens Tri Hita Karana Study Group in the province of Bali. The subject of this study amounted to 90 people citizens study group, divided into five groups to learn life skills in three areas of research. The distribution of the number of subjects in each group can be seen in the following table.

Table: 1. Number of Subjects According to Gender and Life Skills Study Groups Research in Three Areas, namely: Badung, Gianyar, Bali Province and Singaraja regency

\begin{tabular}{lcccccc}
\hline Gender & $\begin{array}{c}\text { Headband } \\
\text { Badung }\end{array}$ & $\begin{array}{c}\text { Dulang } \\
\text { Badung }\end{array}$ & $\begin{array}{c}\text { Silver \&Gold } \\
\text { Gianyar }\end{array}$ & $\begin{array}{c}\text { Naturalistic } \\
\text { CarveAntiques } \\
\text { Gianyar }\end{array}$ & $\begin{array}{c}\text { Coconut } \\
\text { Shell } \\
\text { Singaraja }\end{array}$ & Total \\
\hline Male & 6 & 15 & 7 & 20 & 15 & $\mathbf{6 3}$ \\
Women & 4 & 5 & 3 & - & 15 & $\mathbf{2 7}$ \\
Total & 10 & 20 & 10 & 20 & 30 & 90 \\
\hline
\end{tabular}

Table: 2. Mastery ‘Genera Life Skills’ In Citizens Study Group

in Three Areas, namely: Badung, Gianyar, Bali Province and Singaraja regency (Pre Test)

\begin{tabular}{lc}
\hline \multicolumn{1}{c}{ General Life Skills } & Mastery ‘Genera Life Skills’ (In\%) \\
\hline A. Headband (Badung) & 43,23 \\
B. Dulang (Badung) & 45,71 \\
C. Silver and Gold (Gianyar) & 43,68 \\
D. Naturalistic Carve Antiques (Gianyar) & 43,18 \\
E. Coconut Shell (Singaraja) & 42,58 \\
\hline Mean & $\mathbf{4 3 , 6 8}$ \\
\hline
\end{tabular}

Table: 3. Mastery ‘Genera Life Skills’ In Citizens Study Group in Three Areas, namely: Badung, Gianyar, Bali Province and Singaraja regency (Pre Test and Post Test)

\begin{tabular}{crcc}
\hline \multicolumn{1}{c}{ General Life Skills } & \multicolumn{2}{c}{ Mastery 'Genera Life Skills' (In \%) } \\
\cline { 3 - 4 } & & Pre Test & Post Test \\
\hline A. & Headband (Badung) & 43,23 & 48,15 \\
B. & Dulang (Badung) & 45,71 & 49,40 \\
C. & Silver and Gold (Gianyar) & 43,68 & 47,62 \\
D. & Naturalistic Carve Antiques (Gianyar) & 43,18 & 48,22 \\
E. & Coconut Shell (Singaraja) & 42,58 & 47,75 \\
\hline \multicolumn{2}{c}{ Mean } & $\mathbf{4 3 , 6 8}$ & $\mathbf{4 8 , 2 3}$ \\
\hline
\end{tabular}


If made in a graph, an increase that looks like below

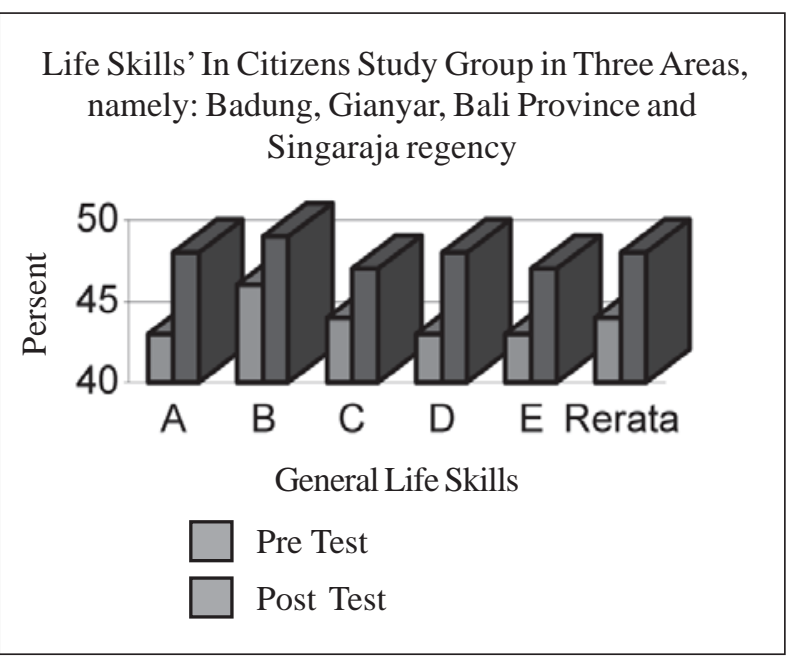

\section{Guidance Material Necessary in the Learning Programme Life Skills Education}

Materials needed for guidance in learning life skills education programs at community learning groups in three districts, namely: Badung, Gianyar, and Singaraja Bali Province are as follows: (1) Guidance is the process of group counseling to foster a sense of responsibility peribadi in the study group, develop mutual understanding among members of the group to learn, build solidarity among members of working groups, a relationship between leaders and others in the group work among members, perform tasks assigned to the group in achieving the target / desired goals together, make decisions collectively, have mutual respect among members group, resolve disputes peacefully among members of other in study groups, and accept with sincere acknowledgment of the differences peribadi working group members and (2) Individual tutoring is the process of guidance to understand the benefits (advantages) and weaknesses of his own, develop symbolic thinking skills and capability make effective communication, capable membelajarkan ourselves, capable of making decisions, directing themselves, develop themselves, and adjust themselves in accordance with the norms prevailing in the learning environment, does not depend on help from others, capable of flexible behavior in communicating with members of the working group, have faith and positive attitude to work together in groups, able to build unity within the group work together, and the existence of mutual respect, willingness to accept with sincerity, and respect for differences in study groups.

\section{Organizing Material Guidance Life Skills Based Tri Hita Karana}

The organization of life skills guidance materials based Tri hita karana can be explained in a matrix of skills to think and act within the scope of the implementation of life skills counseling services.

\section{Thinking Skills}

\section{Acting Skills}

\section{Know Yourself}

Understanding the strengths and weaknesses of themselves and the depanya.

Having beliefs, feelings, or attitude of a person about himself.

Weaknesses: lack of meaning an individual about himself and other people's views about him.

\section{Self Membelajarkan}

Realizing that learning how to learn.

Able to develop a better personality and able to act independently and have a sense of responsibility.

Weaknesses: lacks its own sense of responsibility in learning.
Demonstrates how to master a particular skill with expertise

Analyzing the potential to be developed optimally.

Doing something that does not support his development.

Looking for information on how to effective learning.

Analyzing the usefulness of self-development in learning to improve responsibilities.

Less able to perform self-learning effectively. 
3. Autonomy

Able to make decisions, lead and develop themselves and adjust to the norms prevailing in their environment.

Weaknesses: less able to make decisions regarding themselves and their environment.

\section{Communicative}

Able to convey messages, both verbally and nonverbally.

The success shows that flexible behavior and manage the interaction.

Weaknesses: behave in a less flexible and have no social skills.

5. Cooperative and collaborative

Can work together in groups.

The existence of mutual trust in between group members.

Weaknesses: lack of tolerance and responsibility of a group.

\section{Solidarity}

Able to make decisions collectively, working together, working in a team / group, and able to solve problems peacefully.

The existence of an attitude of mutual respect among members of the group.

Weaknesses: lack of willingness to accept and sincere as well as respect for personal differences.

\section{Academic}

Mastering the basic concepts of science, namely cognitive, affective, and psychomotor.

Master the key concepts of science, namely the main principles and the tree of knowledge.

Weaknesses: lack the skill mastery of the process and less able to apply the concept.

8. Vocational

Applying the key concepts of science.

Weaknesses: lack the skill how to implement processes that must be owned by citizens learn.
Looking for possibilities that lead to self-development and conformance with the norms of society.

Less able to direct himself in accordance with the decision.

Discover how to communicate that communicative.

Analyzing usability appropriate behavior in various behavioral contexts.

Less able to identify maintenance and develop a sense of empathy.

Indicate the nature of good cooperation within the group. Analyzing usability build unity within the group.

Doing something that has no faith and good attitude among members of the group.

Finding possible solutions problems peacefully.

Analyzing decision keguanaan a decision collectively.

Doing something that does not show an attitude of mutual respect.

Demonstrates how to master the basic concepts and scientific concepts

Analyzing usability have process skills, ie skills required.

Less able to apply the concept in everyday life.

Looking for the possibility of applying key concepts of science.

Doing anything less could apply the process skills should be owned in real life day in society. 
Furthermore, how the concept of Tri Hita Karana as a cornerstone in providing counseling services in community living skills can be described as follows:

\begin{tabular}{|c|c|c|c|}
\hline No. & $\begin{array}{l}\text { Concept } \\
\text { Tri Hita Karana }\end{array}$ & $\begin{array}{l}\text { Value - value } \\
\text { of Cultural }\end{array}$ & $\begin{array}{l}\text { General Lifeskills } \\
\text { Citizens Groups } \\
\text { Learning }\end{array}$ \\
\hline
\end{tabular}

1. Parahyangan:

Provide guidance to practice or praying, ceremony Yadnya and Indigenous ceremony

2.

Pawongan:

Provide guidance which shows compliance citizens learn of Reverend and the priests, membership in life Banjar, mekrame Indigenous, and kinship

\section{Palemahan:}

Provide guidance to conserve natural surrounding environment, grow caring love beauty of the environment, and maintain beauty and cleanliness environment in the region workplace
Moksartam jagathitaya caiti dharma: imply picture of human life in the world aims to achieve welfare and the unseen.

Wyapi-wiyapaka: as always remember the principle of human that God is always there everywhere and always remember to pray or worship.

Rwa bhineda: (respect difference / two different) is a growing attitude of mutual understanding between each other.

Jagathita: (happy life and Sejahtra in the world) is that humans are capable of directing themselves and manifest itself in achieving the livelihoods of the world.

Trikaya Parisudha: to teach people to always think (manacika), said (wacika), and acting or doing (Kayika) is good.

Catur purusartha: namely successful realization dharma (good deeds), artha (material / wealth), kama (Pleasure), moksa (Keseimbangan/keharmonisan) in the life daily human.

Tat twan asi: (concept - love, and realize the lives of all living things as a unified whole) is to teach people to always refrain from violence and cruelty.

Karma Phala: (law-cause and effect)

Tri Guna: (three characters / behavior) that is satwan (Wise, honest, loyal), rajas (passionate / greedy), tamas (lazy).

Paras Paros salunglung sabayataka saharpanaya:

Implies a value stance, humans learn to understand and perform tolerant of life practices, unanimous bad destiny.

Anuduhkna ajnyana sandhi: implies man will not do damage, and natural destruction.
Control the situation, motivation to act, willingness to take risks, to understand advantages and disadvantages.

Recognizing ability learning, capable of solve problems own, develop mutual understanding.

Know yourself and environment objectively, make appropriate decisions, directs itself according with the decision, and able to manifest itself.

Able to convey ideas or messages, the behavior flexible, and able to express his feelings.

Able to work on tasks together, the intention and attitude of the members of the group, have a purpose together, and awakening a sense of togetherness.

Demonstrate an attitude of mutual understanding, capable of cooperate, work in groups, solve problems peacefully, and respect for cultural diversity. 
Of the three domains of life skills in the community (Badung, Gianyar, and Singaraja regency of Bali Province), the headband skills, skills platter, skills silver \& gold, antique naturalistic carving skills, and skills of coconut shells, in this study found about guidance Tri Hita Karana is based. The complete description is as follows.

In parahyangan aspect, in every holy days such as Hindus and Tilem Purnama, Galungan and Kuningan holidays (which fall on Wednesdays kliwon wuku Dungulan, as a day of victory of dharma against adharma), the day of Nyepi (the Hindu new year saka), day Tumpek cage (the Hindu holy day that falls every Saturday kliwon uye, namely the ceremony to worship the Sang Hyang Widhi Wasa in manisfestasinya as Sang Hyang Rare Angon, creators and keepers of animals), day Tumpek ubuh / uduh / bubuh (holy day Hindu who falls every Saturday kliwon wuku Wariga, the ceremony to worship the Sang Hyang Widhi Wasa in manisfestation as Sang Hyang Sangkara, creator and maintainer of plants), day Tumpek Landep (Hindu holy days that fall on Saturdays kliwon wuku Saniscara, the ceremony to worship the Sang Hyang Widhi Wasa in its manifestations as Sang Hyang Pasupati, creator and guardian of all human work equipment made of iron or metal), Siwalatri day that falls on every day as a day of prewani tilem kepitu smelting sin, Saraswati Day which falls every umanis Saturday, the ceremony to worship the Sang Hyang Widhi Wasa in its manifestations as Sang Hyang Goddess Saraswati, to request that we be given safety while traveling on science, and the days piodalan at pretending and or pemerajan and so are the days good and holy to praying for every citizen groups living in the community to learn skills which must be implemented by them. Guidance provided by officials here to study / tutor and technical resource person in the learning process and guidance.

Meanwhile, at the ceremony yadnya (holy sacrifice) and traditional ceremonies in the Village area of pekraman, all three domains of learning life skills such as day ceremony of yadnya soma ribek as offerings to worship the god of Rambut Sedana (in silver \& gold skill group), day of tumpek

Meanwhile, at the ceremony yadnya (holy sacrifice) and traditional ceremonies in the village area of pekraman, all three domains of learning life skills such as day ceremony yadnya soma ribek as offerings to worship the god of Rambut Sedana (in silver \& gold skill group), day Tumpek Uduh/Ubuh as offerings for the maintenance of the plants to thrive (in groups of skills platter, antique and naturalistic carving coconut shell), day Tumpek Landep as offerings for the maintenance of equipment of iron or metal (in the skill group headband and naturalistic carving antique). They always deliver to the offering as a form of gratitude to Sang Hyang Widhi Wasa upon His mercy and grace that is given the safety and welfare of mankind in the world. Furthermore, in the implementation of traditional ceremonies, such as human ceremonial yadnya (birth ceremony, rose ceremony adult, dental cutting ceremony, marriage ceremonies, and so on), pitra yadnya ceremony (ritual of death/ngaben, memukur ceremony, and so on), the ceremony of indigenous gods yadnya (piodalan ceremony at the temple/paibon, pemerajan, and so on), they also continue to perform its obligations in preserving traditional values and culture for the sake of stability of Bali (preservation of cultural values and survival Balinese people of Bali).

Pawongan aspect, coaching and guidance given by the civil learning/tutor and technical resource person for always adhering to the instructions of the holy (the clergy or sulinggih) and the traditional leaders / communities to implement the teachings of Hinduism (the holy book Wedha, Sarasamuscaya, Smerthi) and abstain from acts of sin (the law of karma phala). Meanwhile, in the life of village membershi, civil learning/tutor and technical resource persons always give the widest opportunity to learn life skills group residents by giving permission or dispensation to not work and always put the interests of village and custom in the village area of pekraman. Furthermore, the activities of social activities in the area of indigenous pekraman area, civil learning/tutor and technical resource to the residents always instill study groups for foster attitudes Paros paras salunglung sabayantaka saharpanaya (attitude of tolerance and harmonious living bad destiny), tri-kaya parisudha (thinking, say, and do good), and tat twam asi (the concept that guides the universe loves mankind such as love themselves, life mutual respect, mutual respect, full of tolerance, mutual help and mutual), and always cultivate the attitude of mutual life cooperation in the area of indigenous village or pekraman. 
Aspect of palemahan, coaching and guidance given by the civil learning/tutor and technical resource person to keep growing concern and awareness of the environment surrounding especially in a workplace environment in the learning activities, work, and practice always pay attention to the environmental impact so as not contaminated, particularly in skills naturalistic carving platter and skill antique. While in the coconut shells skills group that takes the basic ingredients of unused coconuts (goods waste). The citizen study groups are always reminded to grow a sense of love on the beauty of the surrounding environment to maintain beauty and environmental hygiene in the workplace.

\section{CONCLUSIONS}

One fact that Indonesia as a pluralistic nation has been able to show a harmonious life on the diversity of cultural values existing. These basic values should still serve as the primary basis for guidance to citizens study group in achieving sustainability of the nation. Mastery of general skills life skills (general life skills) as a cornerstone in obtaining and understanding the skills of thinking and acting skills in the learning and work has not been controlled by the citizens group to study in three districts, namely: Badung, Gianyar, and Singaraja Bali Province. Failure or lack of belief in learning and work is not solely because of academic ability and low vocational skills, but because it lacks the skills of how to think and act effectively.

There are various factors that can affect the success of the development model. It can be explained as follows. The establishment of the relationship between the guidance counselor (civil learning / tutor and technical resource persons) and guidance (citizen study groups) in research on the scope of the second year is not independent of the willingness to receive treatment guided in guidance on the one hand and readiness counselor in providing counseling services life skills on the other. Willingness of citizens to receive treatment study group counseling services from the civil life skills learning / tutor, technical resource persons, and advisors / mentors, due to a requirement that must be met. For the citizens group to study the needs in question are (1) the need to actualize themselves in study and work, (2) the need for self-knowledge and self motivated learning, (3) needs to solve its own problems in working life, (4) needs to behave flexibly in communicating with members of the working group, (5) the need to build unity in the working group, and (6) the need to take a decision together in groups and the willingness to accept and sincere inter-member working group. These needs have been obtained in the development of life skills counseling services model (guidance and life skills) based tri hita karana. Conversely, the civil learning / tutor, technical resource persons, and companion / mentor, in the provision of guidance services are conducive to improving its capabilities in terms of (1) realizing life skills counseling program services (guidance and life skills) to improve general skills life skills (general life skills) citizen groups in an optimal learning, and (2) develop and apply psychological functions are integrated into a model to guide the development of citizen groups in an integrated learning towards a more optimal development.

The expectation is also a model life skills counseling services (guidance and life skills) Tri hita karana concept is based on the scope of this second year to work well to improve the local community especially the poor. Furthermore, this model is a model of scientific-practical guidance services that are based on theories of guidance and counseling, life skills established that allows the user according to the needs of study groups who are experiencing learning life skills education program. Model life skills counseling services (guidance and life skills) based on the tri hita karana concept has a different color with a model of guidance services that have been granted by the civil learning / tutor, technical resource persons, and companion / mentor for this, whether subject or procedure. Subjects service model life skills counseling (life skills guidance) based on the tri hita karana concept is not only composed of those who are in the process of learning life skills education program, but also for those who already have the skills (skills) in work, trying and independent. In other words, subjects who are heterogeneous group composed of subjects who are in the process of learning life skills or who already have the skills (skills). In the service model approach to life skills counseling (guidance and life skills) is based the tri hita karana subject is a decisive reason for the need to get help with counseling services, types of support services needed guidance, and purpose of guidance services help his chosen subjects participated even determine the interventions. 
Based on the results of further research (on the scope of the second year - in 2009) was the finding of the model life skills counseling services (guidance and life skills) based on the tri hita karana concept has a very high effectiveness, and adequate internal validity. Therefore it is suggested also that the life skills approach to counseling services (guidance and life skills) based on tri hita karana education was introduced to the audience, especially the civil learning / tutor, technical resource persons, facilitators or mentors, as well as for the organizers or managers at district level as well as village-level managers through the 'special training' regarding its use in society, for the implementation of this model in the field do not become blurred its meaning only because of unfamiliarity to use it. Even though the service model approach to life skills counseling (guidance and life skills) based on tri hita karana, according to empirical data have a very high effectiveness, it would not hurt if done prior to field trials used in the coverage of unity - 2008; coverage of the second year - 2009; and resumed again on the scope of the third year 2010 that can be done simultaneously along with the user. General skills of life skills for citizen study groups will be able to face the challenges of an increasingly complex work and complicated, it is probably not an exaggeration to approach life skills counseling services model (guidance and life skills) based on tri hita karana is recommended studied in depth by the civil learning / tutor, technical resource persons, facilitators or mentors, and organizers or managers both at the district and village-level managers. To avoid more confusion in the use of the procedural model of life skills counseling services (guidance and life skills) based on the tri hita karana would be coaching the learning procedure, would be more beneficial if the service models of approach to life skills counseling (guidance and life skills) are based the tri hita karana is recommended as learning material and to be included into the learning program curriculum.

\section{REFERENCES}

Adimihardja, K. \& Hikmat, H. (2001), Strategi Pemberdayaan Masyarakat. Bandung: Humaniora Utama Press.

Adhiputra, A.A.N. (2002), "Pengembangan Model Layanan Bimbingan Berbasis Nilai Budaya lokal untuk Meningkatkan Kreativitas Anak”. Journal Psikopedagogia, 2 (4), 223-239.
Arwata, M. (2003), “Kesemestaan Tri Hita Karana”. Majalah Gumi Bali Sarad [Salah Makna Tri Hita Karana], vol.38, 34 - 35. Tersedia: http:// www.sarad.bali.com [21 Juli 2003].

Atmaja, P. (1999), Tri Hita Karana dalam Pembangunan Bali. Denpasar: PT. Bali Post.

Bagian Proyek Life Skills Diklusepa. 2002. Direktorat Jenderal Pendidikan Luar Sekolah dan Pemuda Nomor: PKS69/BPLS/VIII/2002, tertanggal; 28 Agustus 2002, Perjanjian Kerja Sama Penyelenggaraan Pendidikan Keterampilan Hidup (Life Skills), Bidang Pendidikan Luar Sekolah dan Pemuda. Jakarta: Depdiknas.

Biro Organisasi Setda Propinsi Bali. (2002), Peraturan Daerah Propinsi Bali No. 4 tahun 2002 tentang Pembentukkan, Susunan Organisasi dan Tata Kerja Unit Pelaksana Teknis Dinas (UPTD) Perda Propinsi Bali.

Budhisantoso, S. (1983), "Ideologi Pancasila dan Tertib Sosial Budaya Bangsa Indonesia”. Journal Analisis Kebudayaan. 2 (1), 8 - 18.

Dahlan, M. D. (2002), "Warna Arah Bimbingan dan Konseling Alternatif di Era Globalisasi”. Journal Psikologi Pendidikan dan Bimbingan. 2 (3), 139 $-155$.

Djulia, E. (2006), "Peran Budaya Lokal dalam Pembentukan Sains”. Journal Mimbar Pendidikan, 2, 21-28.

Direktorat Pendidikan Tenaga Teknis. (2002), Petunjuk Teknis Penyelenggaraan Keterampilan Hidup. Jakarta: Depdiknas.

Fraenkel, J. R. and Wallen, N. E. (1993), How to Design and Evaluate Research in Educaton. New York: Mc.Graw Hill Inc.

Kartadinata, S. (2000), "Pendidikan untuk pengembangan Sumber Daya Manusia Bermutu memasuki abad XXI: Implikasi Bimbingannya”. Journal Psikologi Pendidikan dan Bimbingan. 1 (1), 1 - 12. 
Natawidjaja, R. (2000), "Reposisi program Studi bimbingan dan penyuluhan dalam menjawab tantangan masa depan” (Sebuah Analisis dan rekomendasi mengenai Visi dan Penilaian-Diri Program Studi Bimbingan dan Penyuluhan). Journal Psikologi Pendidikan dan Bimbingan. 1 (2), 71 $-86$.

Nelson-Jones, R. (1997), Practical Counselling \& Helping Skills. Texts and Exercises for the Lifeskills Counselling Model. Fourth Edition. London: British Library Cataloguing in Publication Data.

Pedersen, P.B., et al. (1985), Handbook of CrossCultural Counselling and Therapy. Greenwood Press. Westport, Connecticut London, England.

Sekretaris Negara RI. (1989), Undang-Undang Nomor 2/1989, tentang Sistem Pendidikan Nasional, Jakarta.

Soebadio, H. (1983), “Ke-Bhinneka Tunggal Ika Kebudayaan Nasional”. Journal Analisis Kebudayaan. 2 (1), 5 - 10.

Sukartini, SP. (2002), Model Konseling Keterampilan Hidup untuk Mengembangkan Karakteristik Pribadi yang Tegar, Disertasi Doktor pada Program Pascasarjana UPI Bandung: tidak diterbitkan.
Supriadi, D. (2001), Konseling Lintas-Budaya: Isuisu dan relevansinya di Indonesia. Pidato Pengukuhan Guru Besar Tetap dalam Bidang Bimbingan dan konseling Pendidikan pada Fakultas Ilmu Pendidikan Universitas Pendidikan Indonesia. 18 Oktober 2001.

Surya, M. (1997), Bimbingan untuk Mempersiapkan Generasi Muda Memasuki Abad-21 (Pendekatan Psiko-pedagogis). Pidato Pegukuhan Guru Besar Tetap dalam Psikologi Umum IKIP Bandung, Tanggal 17 Oktober 1997.

Undang-undang Sistem Pendidikan Nasional. (UU RI No.2 Th. 1989) dan Peraturan Pelaksanaannya. (1994), Jakarta: Sinar Grafika.

Unesco-Apnieve. (2000), Belajar Untuk Hidup Bersama Dalam Damai dan Harmoni (alih bahasa WP Natpitupulu), Kantor prinsipal UNESCO untuk Kawasan Asia-Fasifik, Bangkok \& Universitas Pendidikan Indonesia.

Wijaya, A. (2003), Kesemestaan Gaya Bali. Majalah Gumi Bali Sarad [Salah Makna Tri Hita Karana], vol. 38, 30 - 33. Tersedia: http://www.sarad.bali.com [21 Juli 2003]

Yusuf, S. (2003), “Konseling Kecakapan Hidup”. Makalah pada Konvensi Nasional XIII Bimbingan dan Konseling ABKIN, Bandung. 